\title{
WOMEN MUNICIPAL POLITICIANS IN ELECTION NEWS
}

\author{
Author: WAGNER, Angelia \\ PhD Candidate - University of Alberta - Canada \\ angelia@ualberta.ca
}

\begin{abstract}
The news media's fascination with which party is ahead in the polls — otherwise known as the horse race — has raised questions about how well informed voters are about their choices on the ballot box. A preoccupation with campaign strategies, gaffes, and photo-ops leaves journalists with less time to report on issues and platforms. Some scholars argue women are particularly handicapped by horse-race coverage because it can lead to negative evaluations of their electoral viability and because the masculine language used in this type of coverage could depict them as inappropriately aggressive and therefore transgressing traditional gender norms. But this study on newspaper coverage of municipal elections in one Canadian province reveals that journalists treat regular council contests more as a marathon than a horse race. The nature of municipal election coverage
\end{abstract}

suggests journalists treat candidates as a mass group of runners, doing little to distinguish them from each other and rarely speculating on their electoral chances. The real problem for women and men council candidates is not media bias but media invisibility_-getting the coverage they need to build a public profile so voters will support them.

\section{Key words}

Women politicians, horse-race journalism, municipal politics, Canada.

\section{Introduction}

Research on the role of gender in political reporting is based on the assumption that the news media act as gatekeepers to elected office. The belief is journalists defend the traditionally masculine character of legislatures by depicting as odd or out of place any candidate who does not fit the white, male mold of the typical political leader (Samek, 2008; Edwards, 2009). Journalists can raise questions about women's suitability for politics by paying excessive attention to personal matters such as their physical appearance and families (Atkins-Sayre, 2009) and by downplaying more substantive matters such as their leadership qualities and policy priorities (Murray, 2010). Journalists can also raise concerns indirectly by describing politics as a game and by focusing on the campaign itself. Lawrence and Rose argue that "the media's persistent emphasis on gaffes, negativity, and the horse race, and their downplaying of the substantive attributes of female candidates in particular, may skew voters' understandings of the candidates and the issues at stake in any election while fundamentally disadvantaging female contenders" (2010: 64-65). Gendered news coverage could thus harm women's electoral chances. Yet most research on the gendered dimensions of horse-race coverage in particular and on media depictions of women politicians in general focus on elite news organizations covering national politics. This national focus ignores the possibility that journalists do not guard the door to all types of legislative bodies. They might not bring the same passion to covering elections when it does not involve party leaders or star candidates (Semetko \& Boomgaarden, 2007) or when the office sought possesses little prestige or power (Everitt, 2003). 
The nature of Canadian municipal government could make the news media less likely to focus on the municipal horse race. First, political parties do not dominate local politics. Most local elections are nonpartisan, with candidates running as independents, so the news media cannot reduce election coverage to a few political parties and party leaders. Second, municipal elections in Canada are comprised of a series of campaigns (one for mayor and one for council as a whole or for each council seat) with several candidates competing in each one. News outlets also often cover elections in more than one municipality. It is much harder for journalists to focus on strategy when they need to follow several campaigns at once. Third, municipalities are arguably the least prestigious and powerful level of government in Canada because of their constitutional standing as creatures of the province (Lightbody, 2006; Magnusson, 2005) and their smaller financial resources and policy scope. Lower voter turnout for civic elections (Gidengil, Blais, Nevitte, \& Nadeau, 2004; Kushner, Siegel, \& Stanwick, 1997) provides some evidence of lesser prestige.

The distinctiveness of municipal government could extend to the media environment. Non-partisanship could combine with other characteristics of municipal elections to shape news practices in such a way as to produce a form of political reporting substantively different from that at the national level. For example, studies have found few differences in the coverage of women and men municipal candidates (Atkeson \& Krebs, 2008; Wagner, 2010), indicating journalists take a more gender-neutral approach to local election coverage. This raises the possibility that journalists are not barriers to increasing women's involvement in municipal politics in the way they can be in national politics. And considering that most politicians are municipal politicians, understanding the role of the news media in municipal politics can provide important insights into the nature of electoral democracy.

This study therefore investigates how journalists approach election coverage when women seek a regular seat on municipal council. Do they describe municipal elections as sporting matches? Are women candidates depicted as players in the game? And do journalists comment on the likelihood that women candidates will be victorious in the end? I use content analysis to examine newspaper coverage of the 2007 municipal elections in one Canadian province. Campaigns in the central Alberta region were chosen because they provide an opportunity to explore election reporting by different types of newspapers in a variety of municipal contexts while controlling for factors such as political and journalistic cultures. As Goodyear-Grant argues, "journalism is a human endeavour that cannot occur outside the systems of shared meanings produced by a society. Gender as a system of meaning, therefore, affects both the selection and editing of news content, as well as citizens' reaction to news stories" (2013: 6). Examining campaigns in a smaller geographical area enables a more focused approach to the role of gender in political journalism.

The findings of this study reveal that journalists do, in fact, treat women and men municipal candidates as political players but as participants in what could be described as a marathon rather than a horse race. The nature of municipal election coverage means journalists effectively treat council candidates as a large mass of runners, with men crowded in front and women keeping pace right behind them. Far more focused on the smaller lead group of mayoral candidates, journalists occasionally glance at the chase group of council candidates to offer brief updates on their progress. The odd runner who manages to break away from the pack (such as an incumbent) excites some media interest, but those who drop off from the group (such as fringe candidates) soon get forgotten, and this is true regardless of the gender of the candidate. When journalists do talk about council aspirants, they struggle to differentiate among the mass of runners and resort to offering little more than a brief overview of each one's aspirations and qualifications. The result is that many women and men council candidates fail to get noticed by most voters during the election. 


\section{Handicapping the news}

Media invisibility is a problem in an era of decreasing personal contact between politicians and citizens (Bimber \& Davis, 2003), as the news media are one of the main conduits through which candidates promote themselves to voters during an election. Newspapers in particular serve to inform the public about the activities of local government (Mondak, 1995) and are arguably the best source of information about civic elections. But journalists are not passive transmitters of the news. They actively frame political events through what details they choose to highlight or ignore (Entman, 1993), and thus influence the audience's thoughts about a topic (Iyengar \& Simon, 1993) or even what topics to think about (Ross, 2002). A common schemata used in election reporting is the game frame, which involves describing political events as a sport or battle. Lawrence (2000: 97) argues that elections lend themselves to such a frame "because they provide clear chronological markers" that correlate to sports, including resulting in a win, loss, or draw, and they can be described with the same language as sporting events. While some scholars believe horse-race journalism suppresses debate about serious issues (Mendelsohn, 1993, 1996), media interest in the political game might be important in terms of raising the public profile of elections and candidates. Soroka and Andrew (2010: 123) argue that busy voters need horse-race coverage to figure out which of the many politicians to focus their attention on: "By providing highly salient information about the viability of candidates, horse-race coverage can help voters more efficiently manage their news-gathering; in effect, it is a filtering mechanism that can help voters reduce the complexity of electoral choices."

Feminist research, however, suggests some women politicians might be handicapped by the media's obsession with the electoral horse race. Several scholars have observed that the media devote more energy to discussing the electoral chances or fitness for office of women politicians than of men politicians (Falk, 2008; Heldman, Carroll, \& Olson 2005; Khan, 1994b; Valenzuela \& Correa, 2009), while others have seen mixed results depending on which office women seek (Kahn, 1994a; Kahn \& Goldenberg, 1991) or their status as incumbents, challengers, or candidates in open races (Jalalzai, 2006). Some researchers have found no difference in the number of viability assessments between women and men politicians (Banwart, Bystrom, \& Robertson, 2003; Kittilson \& Fridkin, 2008), including during provincial (Everitt, 2003) and mayoral campaigns (Atkeson \& Krebs, 2008). Yet the amount of horserace coverage might not be as important, or as harmful, to women's political ambitions as the tone of media assessments about their electoral chances or suitability. Kropf and Boiney (2001: 93) warn that the media play a strong role in the viability of women politicians. This dynamic affected Elizabeth Dole's bid for the Republican nomination for the United States presidency in 1999. Heldman et al. (2005: 325) argue that negative viability coverage, combined with the "first woman" frame, undermined Dole's campaign by portraying her as "a novelty and an anomaly rather than a serious contender for the presidency, and likely diminished her ability to stay in the race." They suggest that horse-race stories about Dole's difficulty in raising money for her campaign and rumours of her dropping out discouraged new donors from stepping forward (Heldman et al., 2005: 322).

What can make the game frame so problematic for women is the deeply masculine nature of the particular metaphors used in describing politics. Gidengil and Everitt (2002) argue that the news media's continual use of macho metaphors not only reveal but also reinforce the assumption that politics is the domain of men. Women do not fit within this narrative framework because they have not historically been viewed as warriors or boxers. As a consequence, women appear out of place or lacking the "requisite attributes" to participate in politics (Gidengil \& Everitt, 1999: 51). Yet women politicians who do display the requisite masculine attributes do not get treated like "one of the boys" by journalists. Gidengil and Everitt argue that women who engage in a more aggressive form of politics are viewed as violating deeply held gender norms, which causes the media to subject women's actions to a greater degree of interpretation than they do those of men, for whom aggressive behaviour is acceptable. On the other hand, the media might ignore women politicians who conform to gender norms because their behaviour is stereotypical and therefore not 
newsworthy (Gidengil \& Everitt, 2000, 2002, 2003; Everitt \& Gidengil, 2003).

This dynamic means that some women candidates see their competitiveness compromised by media questions about their viability as political actors while others are ignored altogether. Tuchman (1978) argues that the mass media "symbolically annihilate" women by condemning, trivializing, or ignoring them and that this marginalization of women is not accidental - it is the product of specific notions about the appropriate gender roles for women in society. She asserts that the mass media view women as "childlike adornments who need to be protected or they are dismissed to the protective confines of the home" (Tuchman, 1978: 8). In essence, media invisibility occurs when a person or subject receives little or no press attention. Gidengil and Everitt (2000) found that one female party leader was largely rendered invisible in television coverage following the leaders debate during the 1993 Canadian federal election. In their study of the 2005 German national elections, Semetko and Boomgaarden (2005: 167) determined that, aside from chancellor candidate Angela Merkel, female politicians were "marginalized in the news," receiving far less coverage than their numbers warranted. But gender is not the only possible explanation for marginalization in the news. In the case of female leaders, their party's degree of electoral competitiveness also plays a strong role in how much news coverage they receive (Blais, Gidengil, Nadeau, \& Nevitte, 2002). Whatever the cause, media inattention can have serious consequences for a woman's political aspirations. Research on political parties finds that the less public prominence a party has, the less likely citizens are to vote for them (Blais, Gidengil, Fournier, \& Nevitte, 2009). Likewise, candidates who do not appear regularly in news stories during an election cannot build a public profile with voters and might suffer for it at the ballot box (Bryant, 1995; Jenkins, 1999).

Evidence on the dangers of horse-race coverage and viability assessments for women candidates, though, is not conclusive. After examining newspaper coverage of three federal Conservative leadership contests, Trimble (2007) concluded that no evidence existed to support the claim that game framing sidelined women in politics. Instead, characteristics of the campaign itself mattered more: "presence and prominence in news coverage can change over the course of the leadership contest. However, it is also clear prominence is not a straightforward reflection of support or "winnability," as the perceived frontrunner may not be as interesting to the press as other candidates" (Trimble, 2007: 983). The drawback to Trimble's study is that all three women she examined were competitive candidates with considerable professional and/or financial resources seeking to lead a major national party. The possibility of high media visibility was strong. What about game framing and media visibility for women seeking non-elite positions at other levels of government?

\section{Methodology}

This study uses content analysis to examine the news media's use of the game frame, their level of attention to council candidates, and their evaluation of women's potential for electoral success during the 2007 municipal elections in the Canadian province of Alberta. Content analysis is a quantitative research technique that examines the overt messages in a text (Neuendorft, 2002) and therefore enables us to examine the behaviour of journalists because a news page is a product of their selection process (Riffe, Lacy, \& Fico, 2005). When necessary, examples from news coverage will be used to illustrate the results. The content analysis is based on the assumption that journalists and the news organizations that employ them are co-creators of election coverage. News stories are as much the product of individual journalists' personal beliefs and professional routines as they are of news organizations' commercial imperatives, organizational constraints, and editorial stances.

A combination of daily and community newspapers was chosen to assess whether horse-race coverage, media visibility, and viability evaluations were a function of newspaper type. Newspapers were selected for the study based on three criteria: 
publishing frequency, circulation size, and gender composition of the local contest. The first two criteria are an indirect measure of the financial and human resources available to a news outlet to cover the election. Newspapers that print more editions in a given year and distribute more copies of each edition earn more in advertising revenue and thus can employ more journalists than newspapers with a limited publishing schedule and a smaller circulation. Daily newspapers are published five to seven days a week, while for community newspapers it is usually once or twice a week. The third criterion enables news coverage to reflect a mixture of contests involving no women, only one or two women, a mix of women and men, and a majority of women. As a result of these criteria, I selected campaigns in Edmonton, Red Deer, St. Albert, Beaver County, and Millet and the corresponding newspapers of the Edmonton Journal, Edmonton Sun, Red Deer Advocate, St. Albert Gazette, Tofield Mercury, and Millet Pipestone Flyer. I later discovered the Pipestone Flyer did not cover the Millet campaign, so I analyzed its coverage on the county of and city of Wetaskiwin elections instead. Overall, I coded news coverage for 98 candidates: 73 men and 25 women. These candidates campaigned under one of two electoral systems: ward-based (where voters in a defined area select a district representative) and atlarge (where all voters can select all council members). Edmonton and the Beaver and Wetaskiwin counties used a ward-based system for council while the others used an at-large system.

Each newspaper was searched for election stories it printed between September 1 and October 15, 2007, voting day. This six-week period, which covered candidacy announcements in the lead-up to nomination day on September 17, permitted news coverage of women and men candidates to be compared at different stages of the campaign. Stories were retrieved from a number of archival formats with the aim of preserving their original layout. Viewing stories in their original context offers information about the ways in which newspapers depict a subject that cannot be gleaned from the text alone (Budd, Thorp, \& Donohew, 1967; Kress \& van Leeuwen, 1998). For example, candidates who appear in a large photograph enjoy a higher degree of visibility than those who can only be seen in a small head-and-shoulder shot or whose images are not shown at all. The population of news items was narrowed to include only articles written by journalists (and not, for example, candidates) and those that had a direct reference to a council candidate in the text or headline. The final sample contains 182 stories, with the Journal providing 85, the Sun 34, the Advocate 28, the Gazette 12, the Mercury 11, and the Pipestone Flyer 12.

The stories were analyzed using a detailed coding system. The variables dealt with horse-race coverage, framing, candidate visibility, and viability evaluations as well as type of story and story placement. Viability mentions were further evaluated to determine if the overall tone of the story was positive, negative, or neutral/balanced. Each candidate-related variable examined women and men separately, with female candidates and male candidates collapsed into two distinct gender groupings. Put another way, women and men were each examined as a group and not as individual candidates. For example, a news item that named five women candidates only needed to apply a sports metaphor to one of them for the story to be coded as having a game language mention for women. This approach, necessitated by the large number of candidates included in the study, made it difficult to assess the effect of individual competitiveness, such as incumbency, on municipal election coverage. While this limitation means differences in news coverage between women and men could be because of incumbency rather than gender, the fact that men make up three-quarters of Canadian municipal politicians (FCM, 2012) suggests incumbency might itself be gendered. An intercoder reliability test was conducted on 20 per cent of the stories. Alpha scores for the scale variables ranged from 0.752 to 1.000 , while kappa scores for nominal variables ranged from 0.554 to 1.000 . Scores for most nominal variables were above 0.700 , indicating very high agreement among coders (Landis \& Koch, 1977). Coding issues for those that did not meet the standard were discussed and resolved between the two coders before the remaining stories were coded. 


\section{Main findings}

Results from the content analysis confirm a link between a newspaper's publishing frequency and circulation size and its amount of election coverage. The three dailies together produced 80.8 per cent of the articles published about council candidates, or 147 stories out of 182 , with the large-circulation Journal responsible for almost half of the total. In contrast, the three community newspapers printed just 35 stories (19.2\%). Even though the newspapers did cover the election, they did not make it particularly prominent in their pages. A small portion of candidate stories appeared on the front page, page three, or the front of the city section. The campaign also failed to score high on other measures of prominence: one-third of election stories had the largest headline on the page and a small percentage had visual elements such as large photographs to draw attention to a story. Mugshots were more prevalent, appearing in almost half of all stories. The two Edmonton newspapers did try to make it easier for readers to find election stories, often using a graphic - such as a one-column logo or page-wide banner - to distinguish campaign items from regular news. The Journal also put election coverage on the same page most days of the week. The down side to these two techniques is that they made it easier for uninterested readers to avoid election coverage altogether (Franklin and Parry, 1998).

\subsection{Framing}

Do journalists use the game frame in municipal election coverage? The short answer is yes. Journalists used at least one sports metaphor in 57.7 per cent of stories, and applied them significantly more often to men $(84.2 \%)$ than to women $(62.5 \%)$. All six newspapers used game metaphors, though to varying degrees. Dailies (86.7\%) and community newspapers $(75 \%)$ were generally similar in their application of game imagery to male candidates, while dailies $(68.8 \%)$ were significantly more likely than community newspapers (25\%) to do so for female candidates, though this could partly be because one of the weeklies had no women candidates to cover. This finding suggests journalists were more comfortable describing men candidates as political players than women candidates.

The most popular sports terminology in election coverage consisted of variations on the gender-neutral metaphor of running. Journalists routinely had candidates "running" for public office or in a "tough race," while the candidates noted they had "run" for a seat before. But journalists also used aggressive metaphors from the male-dominated worlds of war, football, hunting, hockey, and boxing in their stories. Reporters wrote that one woman politician seeking re-election had taken city hall "by storm" during her first term, while a male candidate "blasted" city hall for being slow in responding to homelessness. Journalists always positioned female and male candidates as the rhetorical aggressors. Male candidates were the ones who took "aim" at salary increases or infrastructure woes, who hoped to "beat" an incumbent, who had a "good shot" at a vacant council seat, or who planned to do one more "blitz" to secure votes. Meanwhile, female candidates "hit" the road again in the final days of the campaign. Neither male nor female candidates were portrayed as victims of rhetorical aggression. While it is beyond the scope of this study to determine how readers reacted to the depiction of women politicians as aggressive and therefore acting against traditional gender norms, these examples reveal that journalists at least treated women council candidates as active players and not passive objects in the political game.

As for story focus, journalists devoted almost as much attention to women candidates' issue positions (43.5\%) as to their campaign activities (44.6\%), but showed much more interest in men's policy ideas (52.5\%) than in their electoral efforts (33.8\%). These results were not statistically significant, either overall or by newspaper type, but they point in the expected direction of the news media treating men as more substantive candidates than women. Breaking down results by individual newspaper, most publications opted to concentrate on substantive issues rather than on the race for all candidates. The tabloid Sun was the notable exception: it devoted a considerable portion of its election coverage to the 
race for both women (84\%) and men (79.4\%). These findings indicate that journalists do use the game frame in municipal election reporting but it is not their sole preoccupation: platforms also matter.

\subsection{Prominence}

The next step to understanding how journalists cover the race at the municipal level is to determine whether or not women candidates are as likely as their male counterparts to be treated as major players. In other words, how prominent are women and men candidates in election news? To answer this question, I evaluated textual and visual aspects of newspaper layout that make candidates more conspicuous to readers. Prominence is understood here as distinct from presence, though both are components of overall news visibility. Women candidates have news presence when they are included in election stories, while news prominence refers to how noticeable they are in that coverage. This study examines the second component: I assess how noticeable women and men candidates are in their respective election coverage. Overall, women appeared in 92 election stories and men in 160. The prominence measures used here are based, in part, on those used by Trimble (2007). My index examines whether a female or male candidate was (1) named in the headline, (2) named in the subhead, (3) named in the text of the story, (4) featured in a pull quote, (5) featured in a photograph, (6) featured in a mugshot, or (7) quoted in the story. A subhead is a secondary headline that can appear above or below the main headline or within the body of the text. A pull quote is a design element that features the words of a person quoted in the story. A mugshot is a small head-and-shoulder picture of a person, and a photograph is a larger picture that features anyone or anything. All of these design elements draw the eye to a particular story, increasing the chance it will be noticed as readers flip through the newspaper. To compute the index, each variable was turned into a dummy variable with "yes" answers coded as "1" and then added together so higher values indicated a higher level of prominence. The minimum value for the index is zero and the maximum value is seven.

Because of the cumulative nature of the index, factor analysis was disregarded as a means of checking for validity because the assumptions of the test do not apply. Factor analysis assumes an index is correlational, or that its component parts overlap in what they measure - as in the case of asking people for their thoughts on appropriate behaviour for women and men to produce a gender-roles attitude index. A cumulative index is comprised of a series of distinct measures. In terms of newspaper layout, not every story is accompanied by a subhead, pull quote, photograph, or mugshot, so the presence of one item does not automatically mean the presence of another. Space constraints often limit how many design features an editor can incorporate into a story's layout. Still, the index has face validity because newspapers rely on such design elements to make their pages more visually appealing to readers, and election stories that incorporate such layout devices are more likely to be read.

Table 1: Prominence of women and men council candidates in six newspapers during the 2007 Alberta municipal elections (as percentage of stories mentioning women or men candidates)

\begin{tabular}{|c|c|c|}
\hline Prominence item & Women & Men \\
\hline Named in story ${ }^{*}$ & $91.3 \%$ & $81.3 \%$ \\
\hline Named in headline & $2.2 \%$ & $3.8 \%$ \\
\hline Named in subhead & $20.7 \%$ & $26.9 \%$ \\
\hline Featured in pull quote & $3.3 \%$ & $2.5 \%$ \\
\hline Featured in photograph & $3.3 \%$ & $8.8 \%$ \\
\hline Featured in mugshot ${ }^{*}$ & $28.3 \%$ & $41.9 \%$ \\
\hline Quoted in story & $64.1 \%$ & $73.8 \%$ \\
\hline \multicolumn{3}{|c|}{$\begin{array}{l}\text { Note: } \mathrm{N}=92 \text { for women and } \mathrm{N}=160 \text { for men for all } \\
\text { items. }\end{array}$} \\
\hline \multicolumn{3}{|c|}{$\begin{array}{l}* \mathrm{p}<.05 ; \text { Independent single sample } t \text {-tests used to } \\
\text { determine the level of significance for differences in } \\
\text { means between women and men council candidates }\end{array}$} \\
\hline
\end{tabular}

Table 1 presents the descriptive statistics for the index variables. Just as newspapers did not make the municipal election itself particularly prominent in their pages, they did not push women and men council candidates into the public's consciousness by featuring them in eye-grabbing layouts. Few men candidates and fewer women candidates were featured in a headline or photograph in their respective news coverage. Women and men only show up consistently in subheads and mugshots, likely because of how some newspapers presented the candidate profiles. On a more positive note, 
newspapers gave both women and men regular opportunities to speak for themselves, quoting them in at least two-thirds of stories.

Table 2: Prominence index score for women and men council candidates during the 2007 Alberta municipal elections, both overall and by newspaper (in means)

\begin{tabular}{|l|l|l|}
\hline Newspaper & Women & Men \\
\hline Edmonton Journal & 2.42 & 2.85 \\
\hline Edmonton Sun & 1.88 & 1.88 \\
\hline Red Deer Advocate & 2.06 & 2.26 \\
\hline St. Albert Gazette & 1.67 & 2.00 \\
\hline Tofield Mercury & 0.00 & 2.00 \\
\hline Millet Pipestone Flyer & 2.33 & 1.89 \\
\hline OVERALL $^{*}$ & $\mathbf{2 . 1 3}$ & $\mathbf{2 . 3 9}$ \\
\hline
\end{tabular}

Note: The $\mathrm{N}$ varies for women and men depending upon the newspaper. The overall value is 92 for women and 160 for men. ${ }^{*} \mathrm{p}<0.05$; The prominence index has a maximum value of seven. Independent single sample $t$-tests used to determine the level of significance for differences in means between women and men council candidates.

However, Table 2 reveals that male candidates were significantly more prominent in municipal election coverage than their female counterparts, though the profile of neither group was all that high. Overall, men had 2.39 prominence markers in each story in which they were mentioned compared to 2.13 for women. This result appeared to be driven by the dailies, which made men significantly more noticeable in their pages than women; men were only slightly more prominent in weeklies. As for individual newspapers, only the Pipestone Flyer made female candidates more prominent in its coverage than male candidates while the Sun made both groups equally noticeable. It should be noted that while the four largest newspapers offered steady coverage of candidates throughout the campaign, the prominence scores for the other two largely stem from the candidate profiles they printed in the week before the vote.
Table 3: Prominence index scores by women and men council candidates during the 2007 Alberta municipal elections, both overall and by time period (in means)

\begin{tabular}{|c|c|c|}
\hline Time period & Women & Men \\
\hline Pre-election & 1.55 & 2.18 \\
\hline Week 1 & 2.32 & 2.45 \\
\hline Week 2 & 2.64 & 2.80 \\
\hline Week 3 & 2.28 & 2.61 \\
\hline Week 4 & 1.88 & 2.06 \\
\hline OVERALL & 2.13 & 2.39 \\
\hline \multicolumn{3}{|c|}{$\begin{array}{l}\text { Note: The N varies for women and men depending } \\
\text { upon the time period. The overall value is } 92 \text { for } \\
\text { women and } 160 \text { for men. The prominence index } \\
\text { has a maximum value of seven. }\end{array}$} \\
\hline
\end{tabular}

One-way ANOVAs were conducted to track any changes in prominence for women and men during various stages of the campaign. As Table 3 shows, men led the way throughout the election. Both men and women's prominence were highest during the second week, possibly reflecting the length of time it took journalists to dig into the issues or put together profiles after nomination day. Although a gender bias is at work in how much newspapers portray women and men as major players in the electoral game, journalistic norms appeared to limit the extent of that distortion. For example, the Advocate was conscientious about being impartial in its coverage. If men were consistently named first in its stories, it was because the newspaper usually mentioned candidates in alphabetical order and the women's last names put them near the bottom of the list. Overall, the low prominence of candidates in election coverage is due more to the subdued layout that the newspapers used. It is hard for any candidate to get noticed when newspapers do not use attentiongrabbing layouts for their election coverage. Their bare-bones approach bucks a growing trend in print journalism toward more engaging layouts to attract younger readers who are used to the elaborate visuals of computers, video games, and high-tech movies and who have access to a greater array of news choices thanks to the Internet (see Zerba, 2008; Poindexter, 2008).

The low media prominence of women and men candidates suggests that journalists do not treat them 
as individual horses in a horse race but as a pack of runners in a marathon. Media commentators keep readers up to date on the pack's progress by offering basic information about candidates' qualifications and ideas, but they do little else to distinguish the individual runners from each other. Voters are left to try to spot the candidates of interest to them in the group of runners. Still, journalists did give voters a slightly clearer view of men candidates. Men's greater prominence in election coverage suggests journalists place them at the front of the pack with women right behind them. This effectively positions women as secondary political players.

\subsection{Viability}

One consequence of journalists treating council candidates as an undifferentiated pack of runners was they did not spend much time speculating about women's - or men's - chances of winning the marathon. Journalists discussed a woman's electoral viability in just 9.8 per cent of stories on female candidates and a man's viability in 13.1 per cent of those on male candidates. On those few occasions when they did evaluate candidates, journalists generally viewed women's chances as positive with only a few negative evaluations. They were slightly more divided about the men's chances, offering a mix of positive, negative, and neutral/balanced evaluations. Journal scribe Scott McKeen was the most forthright in proffering his view of candidates seeking one of Edmonton's 12 council seats: "Speaking of things better left dead, Sheila McKay's political career is trying to revive itself with another run for council in Ward 4" (McKeen, 2007a). Later on in the campaign, McKeen said one male candidate had "the edge in experience" while another one "appears to be winning the sign battle" (McKeen, 2007b). Despite these evaluations, McKeen largely held back from predicting who would win the race for council. He had no such hesitation for the mayoral race. He called the Edmonton contest "a one-man affair." Fellow Journal columnist Paula Simons expected two female incumbents to hold on to their ward seats because they were simply "in a different class from their challengers," with one of them conducting an "exceptionally strong, even slick, campaign" (Simons, 2007). However, Simons devoted most of her column to extolling the virtues of candidates she hoped would get the vote. Other viability references came in the form of journalists labeling someone a "faithful fringe" candidate or a "perennial" candidate who had run for many types of office before without much success.

Compared to community papers, dailies were responsible for all of the viability mentions for female candidates and most of those for male candidates. These results indicate that viability evaluations are mainly the work of dailies and therefore mostly a concern for women campaigning in the cities. Smalltown women candidates seem to escape this attention. The upside to limited viability commentary in municipal election coverage is that women council candidates suffer few of the negative evaluations that typically beset women competing for elite positions, especially at the national level. The downside is that they likely found it harder to attract donors, volunteers, and voters to their campaigns without a horse race to excite interest.

\section{Conclusions}

Through their editorial choices, journalists depicted council contests more like a marathon than a horse race. They portrayed women as viable competitors, but they also signaled to voters that men were the more serious prospects by placing men at the front of the pack of runners. And while the campaign itself was often the focus of stories, journalists consistently made a point of presenting substantial information about both women and men candidates that voters could use to make an informed choice when casting their ballots. What they did not provide were many cues about which candidates were potential winners and thus worth learning more about before Election Day. Both women and men candidates had a hard time getting noticed.

Several factors could help shape coverage of municipal elections in general and of women council candidates in particular. First, gender does appear to exert an influence on how reporters choose to write 
about municipal candidates and how editors choose to present that information. As with federal elections, journalists used sports metaphors, including some from male-dominated activities such as war, to describe the activities of council candidates. This language can depict women as unnaturally aggressive (Sampert \& Trimble, 2003) and therefore in violation of traditional gender roles that expect women to be passive. Yet journalists' preference for gender-neutral imagery from track-and-field and their limited use of more aggressive terminology suggest their linguistic choices in the municipal context do not pose the risk of gender incongruence for local women politicians to nearly the same degree as it might for national women politicians. Gender also appears to work in the background in terms of news prominence: while both women and men were barely noticeable in election coverage, men were slightly, but significantly, more prominent. However, we must be careful not to overstate the importance of this finding either. The minimalist presentation of election coverage means men's visibility advantage was likely imperceptible.

Other factors that could play a role in municipal election coverage are size of the municipality, electoral system, and number of candidates. Big cities are often home to several news organizations that could provide extensive coverage of a woman's candidacy, but the ward system commonly used for city councils often results in a long list of candidates that can prove difficult for journalists to cover. Unlike big cities, small towns do not have a large media industry, creating a monopoly for weekly newspapers that can be detrimental to women candidates if the editor eschews political coverage in favour of other topics viewed of more interest to local readers. Mid-sized communities with a smalltown slate of candidates because of an at-large electoral system but with at least a daily newspaper appear to provide ideal environments for women candidates seeking substantial media attention. Of all the newspapers in this study, the small-market Advocate newspaper stood out as trying to provide balanced coverage of its council candidates and did so with a strong focus on issues. Based on this research, I hypothesize that women seeking to represent big-city wards suffer a media invisibility only surpassed by those campaigning in small towns, whereas women in smaller cities could receive a comparatively strong amount of coverage. Future research needs to examine the role of municipality size, electoral system, and candidate numbers on the municipal media environment to understand what challenges women face when trying to draw attention to their candidacies.

The findings of this study also suggest that theories on media depictions of women politicians require some refinement. Gender remains a salient lens through which journalists view politics, but its impact can be, and often is, mediated by other factors such as the nature of the local news industry. As at the national level, journalists can use gender to distinguish between women and men seeking municipal office, but their general lack of in-depth coverage of council candidates means the differences in coverage are often negligible. The effects of gender are more amplified in national political reporting because of the greater attention paid to federal elections. Women seeking high-profile positions such as party leader have a greater chance of attracting press coverage and, with it, greater sexist coverage. In the end, media invisibility is a double bind for women seeking non-elite political jobs. The lack of media attention means journalists' gender bias will not play a large role in the formation of their public image, while the lack of news coverage means they will not be able to use the media to achieve much of a public profile anyway.

This exploratory study of the gendering of municipal election coverage makes a number of theoretical and empirical contributions to the literatures on gender and politics and on municipal politics. First, by investigating municipal political reporting, it demonstrates that journalists do not automatically act as barriers to public office for women. Variations in political context and type of office combine with different journalistic traditions to produce a variety of media environments that might not disadvantage all women politicians. This research therefore challenges media bias theories that are largely based on observations of how journalists at elite news outlets treat women politicians seeking elite national posts. Future research needs to explore media behaviour in 
a variety of electoral contexts in order to develop a more nuanced understanding of the gendering of political reporting. Second, this study highlights the struggles of non-elite women politicians as they use the media to solicit voter support. My findings demonstrate that media invisibility, rather than media bias, is the primary concern for most women seeking elected office and that scholars need to explore not only what journalists do but what they do not do.

The limitations of this study point to a number of directions for future research. A content analysis of media texts can only address the outcomes of news production processes. It cannot provide insight into the role of news routines, professional norms, organizational constraints, and commercial imperatives in the production of political news. How do journalists respond to criticism of media bias against women politicians and of media preoccupation with the horse race? Do they consciously try to provide balanced coverage of women and men politicians? Do they guard against using sports metaphors in their reporting? Furthermore, do they deliberately take a different approach to covering municipal elections than they do national elections? Interviews with journalists would shed light on the evolution of political reporting. A content analysis also cannot uncover the struggles between journalists and politicians in defining what is considered political news, nor can it disclose how voters respond to that news. Do women municipal politicians, like their national counterparts, feel compelled to emphasize masculine qualities over feminine qualities in order to be viewed as serious political actors? Research on the content of, and the strategies behind, women's political messages would reveal how they might contribute to their own gendering in political news. Finally, it would be useful to systematically measure how voter assessments of women municipal politicians are affected by news reports describing the women in gender-incongruent terms. Answers to these questions will provide a fuller explanation of the gendered nature of political reporting and its electoral implications, as well as enable women politicians to tailor their media strategies to suit their political context.

\section{References}

- Atkeson, L.R., \& Krebs, T.B. (2008). Press coverage of mayoral candidates: The role of gender in news reporting and campaign issue speech. Political Research Quarterly, 61, 239-252.

- Atkins-Sayre, W. (2009). Governor mom: Jane Swift and the body politic.” In J.L. Edwards (Ed.), Gender and Political Communication in America: Rhetoric, Representation, and Display (pp. 129-147). Lanham: Rowman \& Littlefield Publishers, Inc.

- Banwart, M.C., Bystrom, D.G., \& Robertson, T. (2003). From the primary to the general election: A comparative analysis of candidate media coverage in mixed-gender 2000 races for governor and U.S. Senate. American Behavioral Scientist. 46, 658-676.

- Bimber, B., \& Davis, R. (2003). Candidate approaches to election web sites. Campaigning Online: The Internet in U.S. Elections (pp. 43-100). Oxford: Oxford University Press.

- Blais, A., Gidengil, E., Fournier P., \& Nevitte, N. (2009). Information, visibility and elections: Why electoral outcomes differ when voters are better informed. European Journal of Political Research, 48, 256-280.

- Blais, A., Gidengil, E., Nadeau, R., \& Nevitte, N. (2002). The media: Getting out the messages. Anatomy of a Liberal Victory: Making Sense of the Vote in the 2000 Canadian Election (pp. 35-44). Peterborough: Broadview Press.

- Bryant, J. (1995). Paid media advertising. In J.A. Thurber \& C.J. Nelson (Eds.), Campaigns and Elections American Style (pp. 84100). Boulder: Westview Press.

- Budd, R.W., Thorp, R.K., \& Donohew, L. (1967). Content Analysis of Communications. New York: The Macmillan Company. 
- Edwards, J.L. (2009). Visualizing presidential imperatives: Masculinity as an interpretive frame in editorial cartoons, 1988-2008. In J.L. Edwards (Ed.), Gender and Political Communication in America: Rhetoric, Representation, and Display (pp. 165-185). Lanham: Rowman \& Littlefield Publishers, Inc.

- Entman, R.M. (1993). Framing: Toward clarification of a fractured paradigm. Journal of Communication, 43, 51-58.

- Everitt, J. (2003). Media in the Maritimes: Do female candidates face a bias? Atlantis, 27, 90-98.

- Everitt, J., \& Gidengil, E. (2003). “Tough talk: How television news covers male and female leaders of Canadian political parties. In M. Tremblay \& L. Trimble (Eds.), Women and Electoral Politics in Canada (pp. 194-210). Don Mills: Oxford University Press.

- Falk, E. (2008). Women for President: Media Bias in Eight Campaigns. Urbana: University of Illinois Press.

- Federation of Canadian Municipalities. (2012). 2012-Municipal Statistics: Elected Officials Gender Statistics. http://www.fcm.ca/Documents/reports/ Women/Municipal_Statistics_Elected_Officials _Gender_Statistics_EN.pdf

- Franklin, B., \& Parry, J. (1998). Old habits die hard: Journalism's changing professional commitments and local newspaper reporting of the 1997 general election. In B. Franklin \& D. Murphy (Eds.), Making the Local News: Local Journalism in Context (pp. 209-227). London: Routledge.

- Gidengil, E., Blais, A., Nevitte, N., \& Nadeau, R. (2004). Citizens. Vancouver: UBC Press.

- Gidengil, E., \& Everitt. J. (1999). Metaphors and misrepresentation: Gendered mediation in news coverage of the 1993 Canadian leaders' debates. Harvard International Journal of Press/Politics, 4, 48-65.
- Gidengil, E., \& Everitt, J. (2000). Filtering the female: Television news coverage of the 1993 Canadian leaders' debates. Women \& Politics, 21, 105-131.

- Gidengil, E., \& Everitt, J. (2002). Damned if you do, damned if you don't: Television news coverage of female party leaders in the 1993 federal election. In W. Cross (Ed.), Political Parties, Representation and Electoral Democracy in Canada (pp 223-237). Don Mills: Oxford University Press.

- Gidengil, E., \& Everitt, J. (2003). Conventional coverage/unconventional politicians: Gender and media coverage of Canadian leaders' debates, 1993, 1997, 2000. Canadian Journal of Political Science, 36, 559-577.

- Goodyear-Grant, E. (2013). Gendered News: Media Coverage and Electoral Politics in Canada. Vancouver: UBC Press.

- Heldman, C., Carroll, S.J., \& Olson, S. (2005). 'She brought only a skirt': Print media coverage of Elizabeth Dole's bid for the Republican presidential nomination. Political Communication, 22, 315-335.

- Iyengar, S., \& Simon, A. (1993). News coverage of the Gulf crisis and public opinion: A study of agenda-setting, priming, and framing. Communication Research, 20, 365383.

- Jalalzai, F. (2006). Women candidates and the media: 1992-2000 elections. Politics \& Policy, 34, 606-633.

- Jenkins, R.W. (1999). How much is too much? Media attention and popular support for an insurgent party. Political Communication, 16, 429-445.

- Kahn, K.F. (1994a). The distorted mirror: Press coverage of women candidates for statewide office. Journal of Politics, 56, 154173.

- Kahn, K.F. (1994b). Does gender make a difference? An experimental examination of sex stereotypes and press patterns in statewide campaigns. American Journal of Political Science, 38, 162-195. 
- Kahn, K.F., \& Goldenberg, E.N. (1991). Women candidates in the news: An examination of gender differences in U.S. senate campaign coverage. Public Opinion Quarterly, 55, 180-199.

- Kittilson, M.C., \& Fridkin, K. (2008). Gender, candidate portrayals and election campaigns: A comparative perspective. Politics \& Gender, 4, 371-392.

- Kress, G., \& van Leeuwen, T. (1998). Front pages: (The critical) analysis of newspaper layout. In A. Bell \& P. Garrett (Eds.), Approaches to Media Discourse (pp. 186-219). Oxford: Blackwell Publishers Ltd.

- Kropf, M.E., \& Boiney, J.A. (2001). The electoral glass ceiling? Gender, viability, and the news in U.S. Senate campaigns. Women \& Politics, 23, 79-103.

- Kushner, J., Siegel, D., \& Stanwick, H. (1997). Ontario municipal elections: Voting trends and determinants of electoral success in a Canadian province. Canadian Journal of Political Science, 30, 539-553.

- Landis, J.R., \& Koch, G.G. (1977). The measurement of observer agreement for categorical data. Biometrics, 33, 159-174.

- Lawrence, R.G. (2000). Game-framing the issues: Tracking the strategy frame in public policy news. Political Communication, 17, 93-114.

- Lawrence, R.G. \& Rose, M. (2010). Hillary Clinton's Race for the White House: Gender Politics and the Media on the Campaign Trail. Boulder: Lynne Reinner Publishers.

- Lightbody, J. (2006). City Politics, Canada. Peterborough: Broadview Press.

- Magnusson, W. (2005). Are municipalities creatures of the provinces? Journal of Canadian Studies, 39, 5-29.

- McKeen, S. (2007a). Candidates rise to occasion on nomination day. Edmonton Journal, September 18, B1, B4.

- McKeen, S. (2007b). If you're running for council, stop mouthing platitudes. Edmonton Journal, October 1, A12, A14.
- Mendelsohn, M. (1993). Television's frames in the 1988 Canadian election. Canadian Journal of Communication, 18, 149-171.

- Mendelsohn, M. (1996). Television news frames in the 1993 Canadian election. In H. Holmes \& D. Taras (Eds.), Seeing Ourselves: Media Power and Policy in Canada (2nd ed., pp. 8-22). Toronto: Harcourt Brace \& Company.

- Mondak, J. (1995). Newspapers and political awareness. American Journal of Political Science, 39, 513-27.

- Murray, R. (2010). Conclusion, A new comparative framework. In R. Murray (Ed.), Cracking the Highest Glass Ceiling: A Global Comparison of Women's Campaigns for Executive Office (pp. 223-247). Santa Barbara: Praeger.

- Neuendorft, K.A. (2002). The Content Analysis Guidebook. Thousand Oaks: Sage.

- Poindexter, P. (2008). IM, downloading, Facebook, and teen magazines: Gateways or barriers to news? In P. Poindexter, S. Merez, \& A.S. Weiss (Eds.), Women, Men, and News: Divided and Disconnected in the News Media Landscape (pp. 48-62). New York: Routledge.

- Riffe, D., Lacy, S., \& Fico, F.G. (2005). Analyzing Media Messages: Using Quantitative Content Analysis in Research. Mahwah: Lawrence Erlbaum Associates.

- Ross, K. (2002). Women, Politics, Media: Uneasy Relations in Comparative Perspective. Cresskill: Hampton Press, Inc.

- Samek, A.A. (2008). Political skin: (Un)covering the presidential candidates. Feminist Media Studies, 8, 426-429.

- Sampert, S., \& Trimble, L. (2003). 'Wham, bam, no thank you ma'am': Gender and the game frame in national newspaper coverage of election 2000. In M. Tremblay \& L. Trimble (Eds.), Women and Electoral Politics in Canada (pp. 211-226). Don Mills: Oxford University Press. 
- Semetko, H.A., \& Boomgaarden, H.G. (2007). Reporting Germany's 2005 Bundestag election campaign: Was gender an issue? Harvard International Journal of Press/Politics, 12,154-171.

- Simons, P. (2007). Mayor may be shoo-in, but council seats just as vital. Edmonton Journal, October 11, B1, B10.

- Soroka, S., \& Andrew, B. (2010). Media coverage of Canadian elections: Horse-race coverage and negativity in election campaigns. In S. Sampert \& L. Trimble (Eds.), Mediating Canadian Politics (pp. 113-128). Toronto: Pearson Canada.

- Trimble, L. (2007). Gender, political leadership and media visibility: Globe and Mail coverage of Conservative Party of Canada leadership contests. Canadian Journal of Political Science, 40, 969-993.

- Tuchman, G. (1978). Introduction: The symbolic annihilation of women by the mass media. In G. Tuchman, A.K. Daniels, \& J. Benet. Hearth and Home: Images of Women in the Mass Media (pp. 3-38). New York: Oxford University Press.

- Wagner, A. (2010). On their best behaviour? Newspaper journalists' coverage of women municipal candidates in Alberta. Canadian Political Science Review, 5, 38-54.

- Valenzuela, S., \& Correa, T. (2009). Press coverage and public opinion on women candidates: The case of Chile's Michelle Bachelet. International Communication Gazette, 81, 203-223.

- Zerba, A. (2008). Reaching young adults begins with change. In P. Poindexter, S. Merez, \& A.S. Weiss. Women, Men, and News: Divided and Disconnected in the News Media Landscape (pp. 155-174). New York: Routledge.

\section{Forma de Citación}

WAGNER, Angelia: Women municipal politicians in election news. Revista Communication Papers, $\mathrm{N}^{\circ} 5$, páginas 35 a 48. Departamento de Filología y Comunicación de la Universidad de Girona. Recuperado el - de de 2 de: http://www.communicationpapers.es 